pela implantação do serviço militar obrigatório, é o espírito da Revolução de 1932 - esta revolução inacabada, em que Miguel Reale serviu como sargento (parece ironia) - que há de exigir dos nossos jovens, dos nossos professores, dos nossos homens eminentes, mais um tributo - este tributo que abrange outros horizontes e mais vastas perspectivas.

Ninguém melhor do que Miguel Reale para representar o espírito altaneiro de São Paulo, já não digo naquele dístico orgulhoso antigo "non ducor, duco", mas, pelo menos, "pro Brasília fiant eximia", que exige uma participação maior dos bacharéis em Direito, dos filhos desta Casa, nos destinos da nacionalidade.

Miguel Reale não encerra o ciclo da sua existência. Inicia outro ciclo, renovando-se no vigor de seu intelecto, na profundidade de seu conhecimento, na grandeza da sua experiência. Ele não negará, por certo, a sua contribuição a outros postos para os quais, fatalmente, há de ser convocado.

Para encerrar esta solenidade, tenho a honra de passar a presidência ao Professor Guerra Vieira, Magnífico Reitor da nossa Universidade.

\title{
Palavras do Professor Antônio Hélio Guerra Vieira, Magnífico Reitor da USP
}

Ao encerrar esta cerimônia, eu trago ao Professor Emérito Miguel Reale a homenagem que lhe é devida, agora e sempre, pela sua Universidade e por seus amigos de outras escolas eventualmente ausentes, professores, alunos e funcionários.

Abraço o Professor Reale como amigo, em meu nome pessoal, e digo que sempre o apontarei como exemplo e fonte de inspiração.

Está encerrada a sessão. 